\title{
Short communication: Evidence for the presence of a putative odorant-binding protein in bovine colostrum
}

\author{
K. Fukuda, ${ }^{*}$ A. Senda, ${ }^{*}$ T. Ishii, $\dagger$ T. Urashima, ${ }^{*}$ M. Morita, $\ddagger$ and T. Terabayashi§ ${ }^{1}$ \\ *Department of Animal and Food Hygiene, and \\ †Department of Pathobiological Science, Obihiro University of Agriculture and Veterinary Medicine, 2-11 Inada-cho, Obihiro, Hokkaido 080-8555, \\ Japan \\ ¥Tokyo Laboratories, Toko Pharmaceutical Industries Co. Ltd., 199-14 Shikahama, Adachi-ku, Tokyo 123-0864, Japan \\ $\S$ Department of Chemistry, School of Science, Kitasato University, 1-15-1 Kitasato, Sagamihara, Kanagawa 228-8555, Japan
}

\section{ABSTRACT}

Using a combination of PAGE and mass spectrometry for protein identification, we obtained evidence that a putative odorant-binding protein, designated hypothetical protein LOC517854, occurs in bovine colostrum. This protein, termed as a putative bovine colostral odorant-binding protein (bcOBP), consists of 172 AA residues, including a putative 16-AA signal peptide. The theoretical isoelectric point value and molecular mass of the full-length sequence of bcOBP were calculated to be 4.57 and 19604.18 , respectively. The highest sequence similarity (83\%) was observed with a potential pheromone transporter, Allergen Bos d 2 . An odorant-binding protein derived from bovine nasal mucosa showed relatively low sequence similarity (52\%) against bcOBP. Its biological function is unclear, but pheromone transport could be considered. This is the first report of a putative odorant-binding protein in bovine colostrum.

Key words: colostrum, lipocalin, odorant-binding protein, pheromone transport

To date, many studies have been performed to explore bioactive proteins and peptides in bovine milk (Korhonen and Pihlanto, 2007; Möller et al., 2008). In addition to $\mathrm{CN}$, whey proteins such as Ig, lactoferrin, lactoperoxidase, $\alpha-\mathrm{LA}$, and $\beta$-LG became available as commercial products subsequent to the development of industrial-scale purification methods (Korhonen and Pihlanto, 2007). However, most of the proteins and peptides low in abundance in milk that are expected to show bioactivity are not commercially available, nor have they yet been identified. Recently, mass spectrometry has been added to conventional purification techniques, providing a powerful aid in the identification of proteins and peptides in biological materials (Contreras

Received April 16, 2009

Accepted June 23, 2009.

${ }^{1}$ Corresponding author: terabaya@sci.kitasato-u.ac.jp
Mdel et al., 2008). Using these techniques, we aimed to explore minor but potentially bioactive proteins and peptides in bovine colostrum. Partial purification steps and mass spectrometric identification allowed us to detect a putative odorant-binding protein ( OBP) that occurs in bovine colostrum.

Colostrum samples were collected from healthy Holstein-Friesian cows within $2 \mathrm{~d}$ postpartum. One liter of colostrum was thoroughly mixed with 4 vol of chloroform:methanol (2:1, vol/vol; Öhman and Hygstedt, 1968). After centrifugation at $1,400 \times g$ for $30 \mathrm{~min}$, the methanol-water layer in the upper phase was concentrated by rotary evaporation to remove the methanol and then lyophilized. The dried material was dissolved in $50 \mathrm{~mL}$ of water and applied to a column (5 $\times 80 \mathrm{~cm}$ ) of Bio-gel P-2 (Fine, Bio-Rad Laboratories, Hercules, CA). Fractionation was performed using water as the eluent. The elution of proteins and peptides was monitored by UV absorption at 210 and $280 \mathrm{~nm}$ and by the method of Lowry et al. (1951). Fractions containing proteins and peptides that eluted just after the void volume were pooled, and those between 5 and $100 \mathrm{kDa}$ were collected by UF using Amicon Ultra-15 filters (NMWL 5 and $100 \mathrm{kDa}$, Millipore, Billerica, MA). After lyophilization, the resulting fraction was dissolved in $20 \mathrm{~mL}$ of water and loaded onto a Q-Sepharose FF (GE Healthcare UK Ltd., Buckinghamshire, UK) column $(2.5 \times 10 \mathrm{~cm})$ that had been equilibrated with water. The materials not adsorbed by the column were eluted in a single peak. The nonadsorbed fractions were pooled and, when further chromatographed on a Sephadex G-75 (GE Healthcare UK Ltd.) column (2.5 $\times 90 \mathrm{~cm}$ ), separated into 3 peaks. The first peak was collected, lyophilized, and stored at $-20^{\circ} \mathrm{C}$ until used.

All the following procedures were performed at room temperature except where stated. The lyophilized protein $(75 \mu \mathrm{g})$ was dissolved in a buffer $[200 \mathrm{mM}$ Tris- $\mathrm{HCl}$ (pH 6.8), 2\% SDS, $40 \%$ glycerol, $0.04 \%$ bromophenol blue] and heat denatured. Protein separation was performed using a $16.5 \%$ polyacrylamide gel. After migration, the gel was stained using a Dodeca Silver Stain 


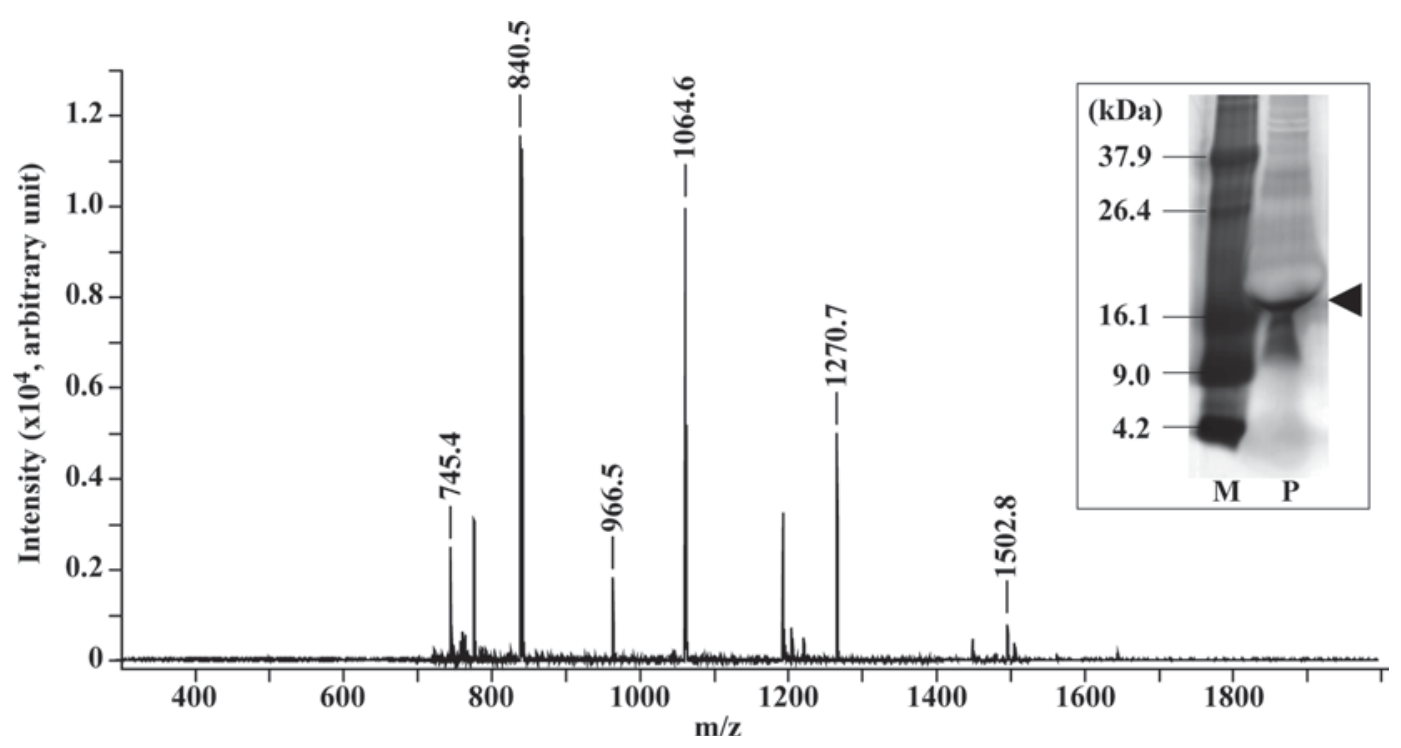

Figure 1. One-dimensional PAGE and mass analysis of tryptic peptides in the partially purified bovine colostrum. Inset, a silver staining image of the one-dimensional PAGE that was done using the first peak separated on a Sephadex G-75 column (GE Healthcare UK Ltd., Buckinghamshire, UK) as a protein sample. $\mathrm{M}=$ molecular size marker; $\mathrm{P}=$ protein sample. An arrowhead indicates the position of the gel excised for the following protein identification procedures.

kit (Bio-Rad Laboratories), according to the instructions of the manufacturer. The major band was excised (Figure 1, inset), and the gel slice was destained by vigorous shaking for $10 \mathrm{~min}$ in the dark with $50 \mu \mathrm{L}$ of $30 \mathrm{~m} M$ potassium ferricyanide:100 $\mathrm{m} M$ sodium thiosulfate $(1: 1, \mathrm{vol} / \mathrm{vol})$. The gel slice was washed 3 times with water, and then thoroughly washed overnight by shaking with $100 \mu \mathrm{L}$ of $10 \%$ acetic acid:methanol (1:1, $\mathrm{vol} / \mathrm{vol})$. The gel slice was transferred to $50 \mu \mathrm{L}$ of 100 $\mathrm{m} M$ ammonium bicarbonate and incubated for $10 \mathrm{~min}$. The solvent was replaced by $50 \mu \mathrm{L}$ of acetonitrile and incubated for $10 \mathrm{~min}$, and then the gel slice was dried with a SpeedVac (Eyela, Tokyo, Japan). Before the ingel digestion, sulfhydryl groups of proteins in the gel slice were protected by reduction with $50 \mu \mathrm{L}$ of $130 \mathrm{mM}$ dithiothreitol in a buffer solution $[6 \mathrm{M}$ urea, $0.375 \mathrm{M}$ Tris- $\mathrm{HCl}$ (pH 8.8), $2 \%$ SDS, $20 \%$ glycerol] and by alkylation in the dark with $50 \mu \mathrm{L}$ of $135 \mathrm{~m} M$ iodoacetamide in the same solution. The gel slice was washed and dried as described above. Proteins were hydrolyzed by an overnight incubation at $37^{\circ} \mathrm{C}$ with $0.3 \mu \mathrm{g}$ of proteomicgrade trypsin (Sigma-Aldrich, St. Louis, MO) dissolved in $30 \mu \mathrm{L}$ of $44 \mathrm{mM}$ ammonium bicarbonate:acetonitrile $(91: 9, \mathrm{vol} / \mathrm{vol})$. Peptides were extracted with $50 \mu \mathrm{L}$ of $0.1 \%$ trifluoroacetic acid:acetonitrile $(1: 1, \mathrm{vol} / \mathrm{vol})$, and the peptide solution was desalted using ZipTip C18 pipette tips (Millipore) according to the instructions of the manufacturer.

The peptide solution $(0.5 \mu \mathrm{L})$ and an equal volume of $10 \mathrm{mg} / \mathrm{mL}$ of 2,5-dihydroxybenzoic acid (Bruker Daltonics, Bremen, Germany) in $0.1 \%$ trifluoroacetic acid:acetonitrile $(2: 1$, vol/vol $)$ were mixed on the target plate (MTP 384 target plate ground steel T F, Bruker). After the solvent dried, the target plate was loaded into the mass spectrometer (AutoflexII TOF/ TOF, Bruker). Mass spectra were obtained using the preinstalled method, RP_1-3kDa (a reflector positive ion mode optimized to the mass range of 1 to $3 \mathrm{kDa}$ ). Peptide calibration standard II (Bruker) was used as an external mass calibrant. The acquired spectra were statistically analyzed using flexAnalysis 2.0 software (Bruker). The peptide mass list (Table 1) was searched using the Biotool 3.0 interface (Bruker) connected to the Mascot search engine (Perkins et al., 1999). Homology search was done using a database at the Web site of the National Center for Biotechnology Information (http://www.ncbi.nlm.nih.gov/).

As the result of protein identification by mass spectrometry, hypothetical protein LOC517854, a putative OBP, was assigned with a probability-based MOWSE (molecular weight search) score of $96(P<0.05)$. Recently, the full-length genome sequence of domesticated cattle has emerged, in which the hypothetical protein LOC517854 coding gene was annotated as MGC151921 OBP-like (gene identification: 517854; The Bovine Genome Sequencing and Analysis Consortium et al., 2009). Of the 13 mass signals acquired, 6 matched LOC517854 (Figure 1 and Table 1). This protein, termed a bovine colostral OBP (bcOBP), consists of 172 AA residues with a putative 16-AA signal peptide (Figure 2), which was predicted by a SignalP 3.0 program at the Center for Biological Sequence Analysis at the Technical Uni- 
FUKUDA ET AL.

Table 1. Mass list of tryptic peptides in the partially purified bovine colostrum

\begin{tabular}{lccl}
\hline Peak identification & Measured $\mathrm{m} / \mathrm{z}$ & Intensity, arbitrary units & Sequences or comments \\
\hline Unmatched & & & \\
2 & 777.4 & $3,158.3$ & Unknown \\
4 & 842.5 & $11,371.0$ & Trypsin autolysate \\
7 & $1,197.6$ & $3,100.5$ & Unknown \\
8 & $1,209.7$ & 710.3 & Unknown \\
9 & $1,225.7$ & 470.0 & Unknown \\
11 & $1,455.8$ & 409.1 & Unknown \\
13 & $1,512.8$ & 318.2 & Unknown \\
Matched & & & \\
1 & 745.4 & $2,343.1$ & ${ }^{28}$ VVGEWR $^{33}$ \\
3 & 840.5 & $11,675.8$ & ${ }^{45}$ IVEGGPLR $^{52}$ \\
5 & 966.5 & $1,675.2$ & ${ }^{34}$ TIYAAADNK $^{42}$ \\
6 & $1,064.6$ & $10,754.9$ & ${ }^{147}$ YQQLNNER $^{154}$ \\
10 & $1,270.7$ & $4,786.8$ & ${ }^{136}$ GTSFTPEEFR $^{146}$ \\
12 & $1,502.8$ & 707.4 & ${ }^{89}$ QEGGVYFIEFEGK $^{101}$ \\
\hline
\end{tabular}

versity of Denmark (http://www.cbs.dtu.dk/services/ SignalP/; Nielsen et al., 1997; Bendtsen et al., 2004). The theoretical isoelectric point value and molecular mass of the full-length sequence of bcOBP were calculated to be 4.57 and 19,604.18, respectively. It was difficult to estimate the yield of bcOBP, because at least 3 proteins were still present as contaminants in the sample prepared in this study. Furthermore, at that time there was no evidence in relation to the existence of bcOBP in mature milk.

Odorant-binding proteins are water-soluble proteins with molecular masses of approximately $19 \mathrm{kDa}$. They belong to the lipocalin superfamily, whose members show low sequence similarity but share a conserved 3-dimensional structure (Flower et al., 2000; Tegoni et al., 2000). Among bovine proteins belonging to the lipocalin superfamily, the highest AA sequence similarity of bcOBP was observed with the Allergen Bos d 2 precursor (83\%). This protein is secreted by bovine sweat glands and causes allergenic reactions in humans, and its function is assumed to be as a pheromone transporter (Mäntyjärvi et al., 1996). However, an OBP derived from bovine nasal mucosa (traditionally abbreviated as $\mathbf{O B P b}$ ) showed relatively low sequence similarity $(52 \%)$ against bcOBP (Tirindelli et al., 1989). Furthermore, the sequence similarity of an OBP found in pig colostrum and milk was $33 \%$ against bcOBP (Guiraudie-Capraz et al., 2005).

The $\mathrm{OBPb}$ was first discovered in bovine nasal epithelium and mucosa as a protein capable of binding pyrazine odorant molecules (Bignetti et al., 1985; Pevsner et al., 1985). To date, OBP expressed in the nasal or vomeronasal organs of mammals have been purified from the cow (Bignetti et al., 1985; Pevsner et al., 1985), elephant (Lazar et al., 2002), mouse (Pes et al., 1992), pig (Dal Monte et al., 1991), porcupine (Felicioli et al., 1993), and rabbit (Dal Monte et al., 1991; Garibotti et al., 1997), among others. The function of OBP in the olfactory organ is controversial. The ligand specificity of $\mathrm{OBPb}$ showed a broad spectrum with dissociation constants in the micromolar range, and the protein is localized selectively in the lateral nasal gland and mucus secretions (Pevsner et al., 1990). Therefore, it was initially assumed that the biological role of $\mathrm{OBPb}$ was in olfaction, such as delivering odorant molecules to receptor sites on olfactory cilia (Pevsner et al., 1990). More recently, other hypotheses have been proposed, including as 1) a pheromone transporter, 2) an odorant scavenger, 3) a regulator of the olfactory receptor, and 4) a transducer of the olfactory receptor (Tegoni et al., 2000; Lazar et al., 2002).

Regarding colostrum and milk, the expression of OBP has been confirmed only in the pig by mass spectrometric identification (Guiraudie-Capraz et al., 2005). Its function was believed to be as a pheromone transporter, based on the evidence that the porcine colostrum-milk OBP could selectively bind to maternal pheromones (Guiraudie-Capraz et al., 2005). Therefore, OBP in maternal fluids, such as amniotic fluid, colostrum, and milk, were assumed to be involved in recognition of the mother by her neonates (Guiraudie-Capraz et al., 2005). One can apply this hypothesis to bcOBP, but further studies are needed to elucidate its biological role. So far, evidence for the existence of OBP in colostrum and milk has been obtained only in the cow and pig; therefore, the distribution of OBP in mammalian colostrum and milk is of additional interest.

In conclusion, with a combination of conventional purification procedures and a proteomic approach, we have obtained evidence that a putative OBP occurs in cow colostrum. Pheromone transport is an attractive candidate for the function of bcOBP, but this remains hypothetical. Our finding suggests that OBP might occur ubiquitously in mammalian colostrum. 
1 AtgAagAtTCtgtTCCTGAGTCTTGTCCTTCTTGTGGTTTGTGCCGCCCAGGAAACtCCA

$$
\begin{array}{llllllllllllllllllllll}
M & \text { K } & \text { I } & \text { L } & \text { F } & \text { L } & \text { S } & \text { L } & \text { V } & \text { L } & \text { L } & \text { V } & \text { V } & \text { C } & \text { A } & \text { A } & \text { Q } & \text { E } & \text { T } & \text { P } & 20
\end{array}
$$

61 GCTGAGATAGACCCCTCAAAGGTTGTAGGAGAGTGGCGCACCATTTATGCAGCTGCAGAT
A $\quad$ E I
S K V
V G
$\begin{array}{llllllll}R & \mathrm{~T} & \mathrm{I} & \mathrm{Y} & \mathrm{A} & \mathrm{A} & \mathrm{A} & \mathrm{D}\end{array}$
40

121 AACAAGGAGAAGATTGTGGAAGGGGGCCCACTGAGGTGTTATAATCGCCACATTGAATGT

$\begin{array}{llllllllllllllllllllll}\mathrm{N} & \mathrm{K} & \mathrm{E} & \mathrm{K} & \mathrm{I} & \mathrm{V} & \mathrm{E} & \mathrm{G} & \mathrm{G} & \mathrm{P} & \mathrm{L} & \mathrm{R} & \mathrm{C} & \mathrm{Y} & \mathrm{N} & \mathrm{R} & \mathrm{H} & \mathrm{I} & \mathrm{E} & \mathrm{C} & 60\end{array}$

181 ATTAACAACTGCGAACAGCTCTCCCTTTCATTTTATATCAAATTTGATGGCACATGCCAG

$\begin{array}{llllllllllllllllllllllllllll}I & N & N & C & E & Q & L & S & L & S & F & Y & I & K & F & D & G & T & C & Q & 80\end{array}$

241 TTTTTCTCAGGAgTGCTACAGAGACAGGAAGGAGGTGTTTACTTCATAGAATTCGAGGGG

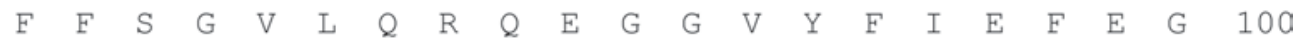

301 AAAATTTATTTGCAAATCATTCATGTAACAGACAACATACTGGTATTTTATTATGAAAAT

$\begin{array}{lllllllllllllllllllll}K & I & Y & L & Q & I & I & H & V & T & D & N & I & L & V & F & Y & Y & E & N & 120\end{array}$

361 GACGATGGAGAAAAGATCACAAAAGTAACTGAAGGTTCCGCCAAAGGAACCAGTTTCACT

$\begin{array}{lllllllllllllllllllll}D & D & G & E & K & I & T & K & V & T & E & G & S & A & K & G & T & S & F & T & 140\end{array}$

421 CCAGAAGAATTTCAGAAGTATCAGCAGCTGAACAATGAGAGGGGGATTCCAAATGAAAAT

$\begin{array}{lllllllllllllllllllll}P & E & E & F & Q & K & Y & Q & Q & L & N & N & E & R & G & I & P & N & E & N & 160\end{array}$

481 ATAGAAAACATCATCGAAACAGACGACTGTCCTCCATAA

$\begin{array}{lllllllllllll}I & E & N & I & I & E & T & D & D & C & P & P & \text { stop }\end{array}$

172

Figure 2. Complementary DNA and AA sequence alignment of the hypothetical protein LOC517854. Boldface indicates the predicted putative signal sequence; $\mathrm{nt}=$ nucleotide; aa $=$ amino acid. The numbers of nucleotides or AA residues are indicated either in the left or right column, respectively.

\section{ACKNOWLEDGMENTS}

We acknowledge O. Kawase and X. Xuan of the National Research Center for Protozoan Diseases, Obihiro University of Agriculture and Veterinary Medicine, for their very useful technical advice on mass spectrometry. We are grateful to M. Messer of The University of Sydney, Australia, for reviewing the manuscript. This study was financially supported by the Research and Development Program for New Bio-industry Initiatives, the Bio-oriented Technology Research Advancement Institution (BRAIN), National Agriculture and Food Research Organization (NARO), Saitama, Japan.

\section{REFERENCES}

Bendtsen, J. D., H. Nielsen, G. von Heijne, and S. Brunak. 2004. Improved prediction of signal peptides: SignalP 3.0. J. Mol. Biol. 340:783-795.

Bignetti, E., A. Cavaggioni, P. Pelosi, K. C. Persaud, R. T. Sorbi, and R. Tirindelli. 1985. Purification and charactrisation of an odorant-binding protein from cow nasal tissue. Eur. J. Biochem. $149: 227-231$.
The Bovine Genome Sequencing and Analysis Consortium, C. G. Elsik, R. L. Tellam, K. C. Worley, R. A. Gibbs, D. M. Muzny, G. M. Weinstock, D. L. Adelson, E. E. Eichler, L. Elnitski, R. Guigó, D. L. Hamernik, S. M. Kappes, H. A. Lewin, D. J. Lynn, F. W Nicholas, A. Reymond, M. Rijnkels, L. C. Skow, E. M. Zdobnov, L. Schook, J. Womack, T. Alioto, S. E. Antonarakis, A. Astashyn, C. E. Chapple, H. C. Chen, J. Chrast, F. Câmara, O. Ermolaeva, C. N. Henrichsen, W. Hlavina, Y. Kapustin, B. Kiryutin, P. Kitts, F. Kokocinski, M. Landrum, D. Maglott, K. Pruitt, V. Sapojnikov, S. M. Searle, V. Solovyev, A. Souvorov, C. Ucla, C. Wyss, J. M. Anzola, D. Gerlach, E. Elhaik, D. Graur, J. T. Reese, R. C. Edgar, J. C. McEwan, G. M. Payne, J. M. Raison, T. Junier, E. V. Kriventseva, E. Eyras, M. Plass, R. Donthu, D. M. Larkin, J. Reecy, M. Q. Yang, L. Chen, Z. Cheng, C. G. Chitko-McKown, G. E. Liu, L. K. Matukumalli, J. Song, B. Zhu, D. G. Bradley, F. S. Brinkman, L. P. Lau, M. D. Whiteside, A. Walker, T. T. Wheeler, T. Casey, J. B. German, D. G. Lemay, N. J. Maqbool, A. J. Molenaar, S. Seo, P. Stothard, C. L. Baldwin, R. Baxter, C. L. Brinkmeyer-Langford, W. C. Brown, C. P. Childers, T. Connelley, S. A. Ellis, K. Fritz, E. J. Glass, C. T. Herzig, A. Iivanainen, K. K. Lahmers, A. K. Bennett, C. M. Dickens, J. G. Gilbert, D. E. Hagen, H. Salih, J. Aerts, A. R. Caetano, B. Dalrymple, J. F. Garcia, C. A. Gill, S. G. Hiendleder, E. Memili, D. Spurlock, J. L. Williams, L. Alexander, M. J. Brownstein, L. Guan, R. A. Holt, S. J. Jones, M. A. Marra, R. Moore, S. S. Moore, A. Roberts, M. Taniguchi, R. C. Waterman, J. Chacko, M. M. Chandrabose, A. Cree, M. D. Dao, H. H. Dinh, R. A. Gabisi, S. Hines, J. Hume, S. N. Jhangiani, V. Joshi, C. L. Kovar, L. R. Lewis, Y. S. Liu, J. Lopez, M. B. 
Morgan, N. B. Nguyen, G. O. Okwuonu, S. J. Ruiz, J. Santibanez, R. A. Wright, C. Buhay, Y. Ding, S. Dugan-Rocha, J. Herdandez, M. Holder, A. Sabo, A. Egan, J. Goodell, K. Wilczek-Boney, G. R. Fowler, M. E. Hitchens, R. J. Lozado, C. Moen, D. Steffen, J. T. Warren, J. Zhang, R. Chiu, J. E. Schein, K. J. Durbin, P. Havlak, H. Jiang, Y. Liu, X. Qin, Y. Ren, Y. Shen, H. Song, S. N. Bell, C. Davis, A. J. Johnson, S. Lee, L. V. Nazareth, B. M. Patel, L. L. Pu, S. Vattathil, R. L. Williams Jr., S. Curry, C. Hamilton, E. Sodergren, D. A. Wheeler, W. Barris, G. L. Bennett, A. Eggen, R. D. Green, G. P. Harhay, M. Hobbs, O. Jann, J. W. Keele, M. P. Kent, S. Lien, S. D. McKay, S. McWilliam, A. Ratnakumar, R. D. Schnabel, T. Smith, W. M. Snelling, T. S. Sonstegard, R. T. Stone, Y. Sugimoto, A. Takasuga, J. F. Taylor, C. P. Van Tassell, M. D. Macneil, A. R. Abatepaulo, C. A. Abbey, V. Ahola, I. G. Almeida, A. F. Amadio, E. Anatriello, S. M. Bahadue, F. H. Biase, C. R. Boldt, J. A. Carroll, W. A. Carvalho, E. P. Cervelatti, E. Chacko, J. E. Chapin, Y. Cheng, J. Choi, A. J. Colley, T. A. de Campos, M. De Donato, I. K. Santos, C. J. de Oliveira, H. Deobald, E. Devinoy, K. E. Donohue, P. Dovc, A. Eberlein, C. J. Fitzsimmons, A. M. Franzin, G. R. Garcia, S. Genini, C. J. Gladney, J. R. Grant, M. L. Greaser, J. A. Green, D. L. Hadsell, H. A. Hakimov, R. Halgren, J. L. Harrow, E. A. Hart, N. Hastings, M. Hernandez, Z. L. Hu, A. Ingham, T. Iso-Touru, C. Jamis, K. Jensen, D. Kapetis, T. Kerr, S. S. Khalil, H. Khatib, D. Kolbehdari, C. G. Kumar, D. Kumar, R. Leach, J. C. Lee, C. Li, K. M. Logan, R. Malinverni, E. Marques, W. F. Martin, N. F. Martins, S. R. Maruyama, R Mazza, K. L. McLean, J. F. Medrano, B. T. Moreno, D. D. Moré, C. T. Muntean, H. P. Nandakumar, M. F. Nogueira, I. Olsaker, S. D. Pant, F. Panzitta, R. C. Pastor, M. A. Poli, N. Poslusny, S. Rachagani, S. Ranganathan, A. Razpet, P. K. Riggs, G. Rincon, N. Rodriguez-Osorio, S. L. Rodriguez-Zas, N. E. Romero, A. Rosenwald, L. Sando, S. M. Schmutz, L. Shen, L. Sherman, B. R. Southey, Y. S. Lutzow, J. V. Sweedler, I. Tammen, B. P. Telugu, J. M. Urbanski, Y. T. Utsunomiya, C. P. Verschoor, A. J. Waardenberg, Z. Wang, R. Ward, R. Weikard, T. H. Welsh Jr., S. N. White, L. G. Wilming, K. R. Wunderlich, J. Yang, and F. Q. Zhao. 2009. The genome sequence of taurine cattle: A window to ruminant biology and evolution. Science 324:522-528.

Contreras Mdel, M., I. López-Expósito, B. Hernández-Ledesma, M. Ramos, and I. Recio. 2008. Application of mass spectrometry to the characterization and quantification of food-derived bioactive peptides. J. AOAC Int. 91:981-994.

Dal Monte, M., I. Andreini, R. Revoltella, and P. Pelosi. 1991. Purification and characterization of two odorant-binding proteins from nasal tissue of rabbit and pig. Comp. Biochem. Physiol. B 99:445-451.

Felicioli, A., M. Ganni, M. Garibotti, and P. Pelosi. 1993. Multiple types and forms of odorant-binding proteins in the Old-World porcupine Hystrix cristata. Comp. Biochem. Physiol. B 105:775784

Flower, D. R., A. C. North, and C. E. Sansom. 2000. The lipocalin protein family: Structural and sequence overview. Biochim. Biophys. Acta 1482:9-24.
Garibotti, M., A. Navarrini, A. M. Pisanelli, and P. Pelosi. 1997. Three odorant-binding proteins from rabbit nasal mucosa. Chem. Senses 22:383-390.

Guiraudie-Capraz, G., M. C. Slomianny, P. Pageat, C. Malosse, A. H. Cain, P. Orgeur, and P. Nagnan-Le Meillour. 2005. Biochemical and chemical supports for a transnatal olfactory continuity through sow maternal fluids. Chem. Senses 30:241-251.

Korhonen, H., and A. Pihlanto. 2007. Technological options for the production of health-promoting proteins and peptides derived from milk and colostrum. Curr. Pharm. Des. 13:829-843.

Lazar, J., D. R. Greenwood, L. E. L. Rasmussen, and G. D. Prestwich. 2002. Molecular and functional characterization of an odorant binding protein of the Asian elephant, Elephas maximus: Implications for the role of lipocalins in mammalian olfaction. Biochemistry 41:11786-11794.

Lowry, O. H., N. J. Rosebrough, A. L. Farr, and R. J. Randall. 1951. Protein measurement with the Folin phenol reagent. J. Biol. Chem. 193:265-275

Mäntyjärvi, R., S. Parkkinen, M. Rytkönen, J. Pentikäinen, J. Pelkonen, J. Rautiainen, T. Zeiler, and T. Virtanen. 1996. Complementary DNA cloning of the predominant allergen of bovine dander: A new member in the lipocalin family. J. Allergy Clin. Immunol. 97:1297-1303

Möller, N. P., K. E. Scholz-Ahrens, N. Roos, and J. Schrezenmeir. 2008. Bioactive peptides and proteins from foods: Indication for health effects. Eur. J. Nutr. 47:171-182.

Nielsen, H., J. Engelbrecht, S. Brunak, and G. von Heijne. 1997. Identification of prokaryotic and eukaryotic signal peptides and prediction of their cleavage sites. Protein Eng. 10:1-6.

Öhman, R., and O. Hygstedt. 1968. The isolation of sialyllactosides with the aid of gel filtration. Anal. Biochem. 23:391-402.

Perkins, D. N., D. J. C. Pappin, D. M. Creasy, and J. S. Cottrell. 1999. Probability-based protein identification by searching sequence databases using mass spectrometry data. Electrophoresis 20:3551-3567.

Pes, D., M. Dal Monte, M. Ganni, and P. Pelosi. 1992. Isolation of two odorant-binding proteins from mouse nasal tissue. Comp. Biochem. Physiol. B 103:1011-1017.

Pevsner, J., V. Hou, A. M. Snowman, and S. H. Snyder. 1990. Odorant-binding protein. Characterization of ligand binding. J. Biol. Chem. 265:6118-6125.

Pevsner, J., R. R. Trifiletti, S. M. Strittmatter, and S. H. Snyder. 1985. Isolation and characterization of an olfactory receptor protein for odorant pyrazines. Proc. Natl. Acad. Sci. USA 82:3050-3054.

Tegoni, M., P. Pelosi, F. Vincent, S. Spinelli, V. Campanacci, S. Grolli, R. Ramoni, and C. Cambillau. 2000. Mammalian odorant binding proteins. Biochim. Biophys. Acta 1482:229-240.

Tirindelli, R., J. N. Keen, A. Cavaggioni, E. E. Eliopoulos, and J. B. C. Findlay. 1989. Complete amino acid sequence of pyrazine-binding protein from cow nasal mucosa. Eur. J. Biochem. 185:569-572. 